\title{
Mineralogy of Iron Ores of Different Alumina Levels from Singhbhum Belt and Their Implication on Sintering Process
}

\author{
Moni Sinha', Sri Harsha Nistala1', Sanjay Chandra', Tilak Raj Mankhand ${ }^{2}$ \\ ${ }^{1}$ Research and Development, Tata Steel, Jamshedpur, India \\ ${ }^{2}$ Department of Metallurgical Engineering, Indian Institute of Technology (Banaras Hindu University), Varanasi, \\ India \\ Email: moni.sinha@tatasteel.com
}

Received 7 May 2015; accepted 23 May 2015; published 26 May 2015

Copyright (C) 2015 by authors and Scientific Research Publishing Inc.

This work is licensed under the Creative Commons Attribution International License (CC BY). http://creativecommons.org/licenses/by/4.0/

(c) (i) Open Access

\section{Abstract}

To increase the life of the mines, ores of lower quality are blended with the higher quality ores. In general, the blending of ores at mines site is controlled by the chemical composition of the ores by controlling the $\mathrm{Al}_{2} \mathrm{O}_{3}$ and $\mathrm{SiO}_{2}$ levels on the lowest side possible. However, if there is a change in mineralogy, like an increase in hydrous phase the composition may still be the same, but this difference may affect the sinterability and sinter quality. The mineralogical investigation of iron ores and their chemistry are required to avoid the increase in deleterious elements during sintering. By the know-how of the behavior of individual iron ores in terms of their sinterability, in advance, the quality of the iron ores blend can be optimized to produce quality sinter and productivity. Characterisation studies conducted on iron ores of Singhbhum Orissa belt revealed that hematite, goethite, clay, gibbsite and quartz occur in all the iron ore samples but in variable proportions. Traces of alumina, present as solid solution in the iron oxide minerals, has also contributed $\mathrm{Al}_{2} \mathrm{O}_{3}$ to the ores.

Keywords

Singhbum, Iron Ore, Sintering, Alumina

\section{Introduction}

Iron is found in many mineralogical forms, but only a few are used as commercial sources, the most important of which are oxides (Hematite $\mathrm{Fe}_{2} \mathrm{O}_{3}$, Magnetite $\mathrm{Fe}_{3} \mathrm{O}_{4}$, and Limonite $\mathrm{Fe}_{2} \mathrm{O}_{3} \cdot 2 \mathrm{H}_{2} \mathrm{O}$ \& Goethite $\mathrm{Fe}_{2} \mathrm{O}_{3} \cdot \mathrm{H}_{2} \mathrm{O}$ ). Oth- 
er less important sources are Carbonates $\left(\mathrm{FeCO}_{3}\right)$, Sulphides $\left(\mathrm{Pyrite} \mathrm{FeS}_{2}\right)$ and Silicates like Chamosite, Grunerite etc. with complex chemical formulae. The main impurities in iron ore are $\mathrm{SiO}_{2}, \mathrm{Al}_{2} \mathrm{O}_{3}, \mathrm{~S}, \mathrm{P}, \mathrm{TiO}_{2}$, and $\mathrm{Na}_{2} \mathrm{O}$ $\& \mathrm{~K}_{2} \mathrm{O}$. Each steel company has its own blast furnace practice and the impact of these impurities varies accordingly. Iron ore is being used for iron and steel production. It is being used in two forms, lump and fines. The lump is used directly in the blast furnace or for direct reduction in alternative ironmaking processes. The fines are used as agglomerates (sinter/pellet) after some more preparation.

The performance of a sinter depends both on the characteristics of the raw materials and the operational parameters. Among raw materials due to its major quantity, the iron ore plays the most significant role in sintering and hence the iron ore should have better metallurgical properties like high reducibility $>70 \%$, low degradation index, high softening and melt-down characteristics. Sintering process is extremely complex due to very short time. The material has complex melting behavior due to different constituents. The physico-chemical nature of raw materials governs the reactions of the mix. The degree of complexity further increases with increasing number of ore fines in the mixture. Quite different behaviors of different iron ore fines are observed at higher temperatures. The complexity of the reaction poses difficulties to optimize the process and hence the quality of the sinter. In the sintering process, the iron ore corresponds to the mixture of hematite, goethite and other gangue mineral typologies. However the goethite and gangue contents are relatively lower than the hematite, but the goethite + gangue to hematite ratio influences the reactivity during sintering. The minerals association in iron ores and their chemistries affect the formation and composition of sinter phases during sintering. Goethite is important as it carries deleterious impurities for steel making. The effect of texture is equally important as it affects the reactivity and/or assimilation of iron ore minerals and subsequently the formation of pores during sintering.

Thus increasing the knowledge on the characteristics of different ore types and its influence on sinter quality will also enable controlling the physicochemical properties of primary sinter melts and will be beneficial to control sintering process to produce quality sinters.

\section{Influence of Iron Ore Mineralogy on Sinter Strength}

The iron bearing minerals have different characteristics. The metallurgical properties of an ore depend on its specific mineralogy and textural characteristics, including the nature of the pore spaces. The iron-bearing minerals themselves contain impurities and the gangue minerals contain some iron phases. These may either be chemically bonded or so finely intergrown that they are difficult to remove by physical beneficiation. The nature of the gangue, particularly its amount and distribution of the alumina-bearing minerals is important apart from their fusibility and sinterability [1] [2].

\subsection{Mineralogy of Iron Ore}

The mineralogy of iron ore varies from quite simple hematite and quartzite with little of aluminium mineral to hydrated hematite along with complex gangue minerals like hydrated aluminium silicate or kaolinite $\mathrm{Al}_{4}\left(\mathrm{SiO}_{10}\right)\left(\mathrm{OH}_{8}\right)$ and trihydratedaluminium oxide or gibbsite $\mathrm{Al}(\mathrm{OH})_{3}$. The hematite can be partially hydrated (goethite, $\mathrm{FeOOH}$ ) or deoxidized (magnetite $\mathrm{Fe}_{3} \mathrm{O}_{4}$ ). In some ore bodies the quartzite is the predominant gangue mineral and significantly low alumina bearing mineral. Some ore bodies, on the other hand, may contain mainly magnetite and only a very little hematite. The gangue may vary from simple to complex type (Figure 1 ) as mentioned above. The extent of hematite or magnetite and total iron content and any of the impurities varies from source to source. All these types may have different behavior during sintering.

\subsection{Effect of Goethite}

Goethite in general comprises a low amount in the ores; however, it can be relevant in the reactivity during sintering. Goethite often carries aluminium in solid solution as well as minor, but significant, amounts of adsorbed phosphorus [3]. It has a variable microtexture and internal porosity. Goethitic ores can vary greatly in hardness ranging from finely crystalline, soft and clayey (limonitic) to hard and vitreous in appearance. These variations results in an associated variation in metallurgical behaviour of the ores.

Although goethite is completely consumed during the sintering processes, its control in the sintering burden is very important due to the impurities present in its composition, which can affect in different ways the distribution of elements in the sinter phases [4]. The compositional aspects of sinters, which are inherited from the ore minerals, are partially related to the reactivity behavior, which can be completely distinct if the hematite/goethite 


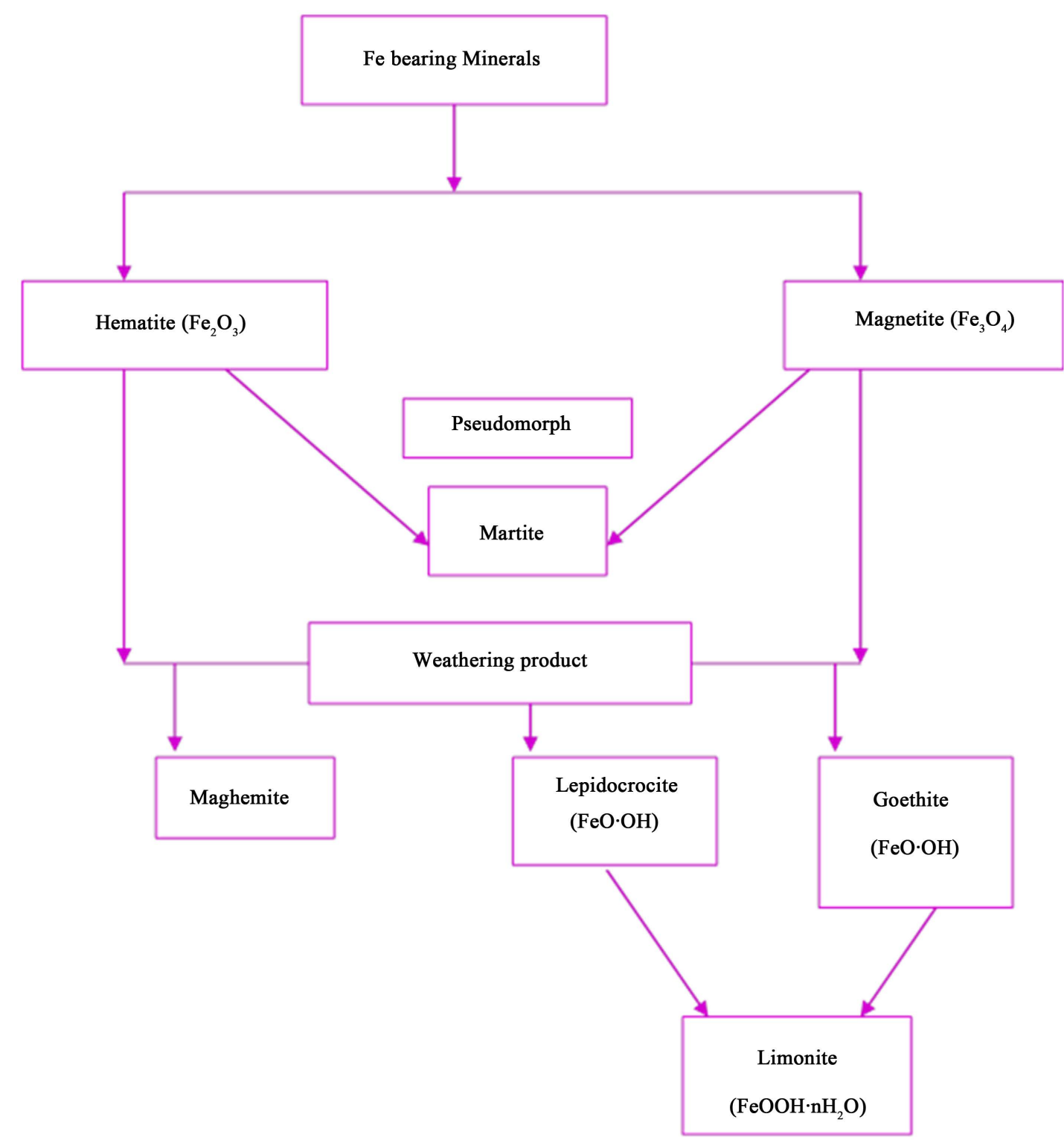

Figure 1. Flow chart showing the relation between different iron minerals.

ratio varies largely. The variation of this ratio can indirectly affect the performance of sinters like mechanical strength and reducibility [3]. Goethitic ores reduces the heat available during the meling period and results in the formation of more viscous high $\mathrm{Fe}_{2} \mathrm{O}_{3}$ melts, thus more coke is required to maintain the level of melt superheat and thus prevent deterioration in sinter strength [1]. Due to presence of goethite there is deterioration in granulation efficiency, for the same bed permeability, the bed containing goethitic ore have a faster flame front speed than the bed with denser ores. Goethitic ores assist in the production of more porous sinters, which are more reducible as these ores/phases are porous nature and have high combined water [1].

\subsection{Effect of Al Bearing Minerals: Gibbsite and Kaolinite}

It is generally believed that too much alumina impairs the sinter quality, particularly the low temperature reduction degradation characteristics [5] [6]. For every 1\% increase in alumina coke breeze consumption increase by 5 - $10 \mathrm{~kg} / \mathrm{t}$ for an increase in temp by $30^{\circ} \mathrm{C}$. High alumina percentage in ores results in high sintering temperature, longer sintering time, increase in fuel rate and lower productivity. These can be attributed to poor reactivity of the phase and high viscosity of the primary melt [2]. 
Iron ores can have two major types of alumina bearing phases, alumino silicates like kaolinite, while the other phase is gibbsite (alumina hydroxide). However, it was observed that kaolinite containing ore generates melilite as a slag forming mineral whereas gibbsite type ores forms calcium ferrite [2]. These in turn have different effect on the cold strength of the sinter [7].

\subsection{Effect of Ore Texture}

Ore micro-pelletising efficiency and reactivity in sintering and melting reactions are controlled, to a first approximation by crystal size. These properties are enhanced as the crystal size decreases. Crystal morphology is also important because of its influence on particle surface roughness. Low ore porosity and the presence of liberated and fine quartz particles, are beneficial to sinter physical and mechanical properties.

As the ore contains less alumina less of it will go to sinter's molten part to form multi-component hematite or SFCA (Silico Ferrite of Calcium and Alumina) and the RDI (Reduction Degradation Index) will be remarkably improved. The smaller crystal size and higher open porosity of ores benefits the reducibility of the sinters produced with low energy input as these crystals remain in the relict or unmoltenore particles found in the sinter. To summarise Iron ores with fine crystal size coupled with low degree of hydration favours high productivity and low coke rate in sintering. Iron ores with medium crystal size and very low degree of hydration favours sinter tumbling strength and RDI.In another study carried out by Okazaki et al. [8] it was observed that in Indian ore there were originally many pores in a part of goethite, which coalesced during heating; furthermore porosity in martite grains seemed to reduce. Surface of the Indian Ore turned granular during sintering upto $1200^{\circ} \mathrm{C}$. The change implied that martite had re-crystallised, or the goethite decomposed to grow such granules. In an assimilation of this ore with limestone powder SFCA developed well between relict ores different mineral phases have variations in crystal size, shape and orientation that reflect differences in their mode of formation (tectonism, degree of metamorphism, supergene changes, etc.). Significantly, they express varying degrees of microporosity and grain density, which are relevant for determining hardness, friability and metallurgical properties such as reducibility and reactivity with fluxes. There is, again, an associated variation in metallurgical behaviour [9]. Some effect of ore texture on sinter microstructure is shown in Figure 2 below.

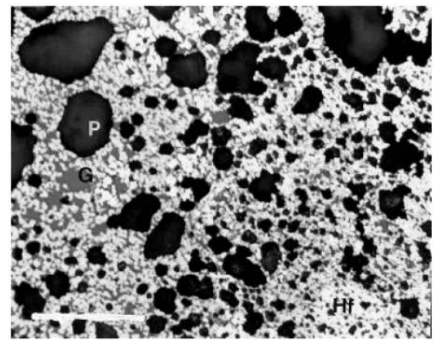

(a)

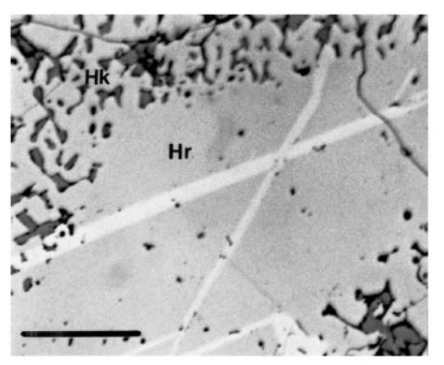

(c)

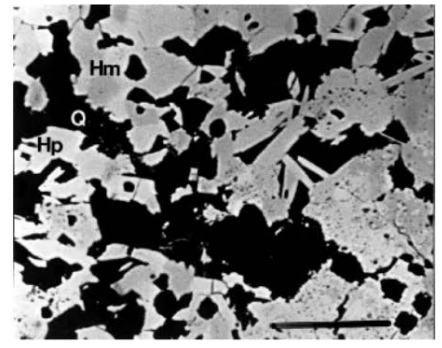

(b)

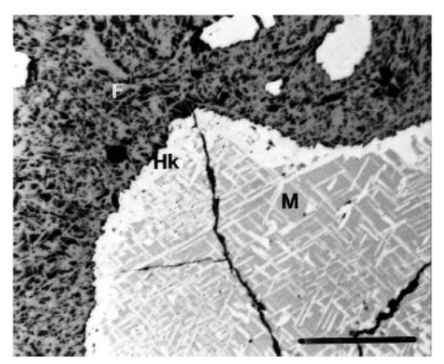

(d)

Figure 2. Reflected-light photomicrographs illustrating ore textures when encapsulated in sinter: (a) Finely granular hematite set in a glassy matrix from a type 4 (fluviatile) ore; (b) Relict martitic and microplaty hematite from a siliceous type 4/2 (medium-grade hematite) ore; (c) Coarsely crystalline hematite from concentrates made from a type 2 (BIF) and showing the typical reduction/oxidation reaction marginal to the sinter melt; (d) Partly oxidized magnetite from a type 7 ore showing the reaction and oxidation rim against the calcium ferrite-rich sinter melt. F, SFCA; G, glass; $\mathrm{H}$, hematite; f, finely crystalline; k, recrystallised; $\mathrm{m}$, martitic; $\mathrm{p}$, microplaty; r, relict; $\mathrm{M}$, magnetite; P, pore space; Q, quartz. Length of scale bar, $0.1 \mathrm{~mm}$. 


\section{Geology of the Iron Ore Deposits}

The Singhbhum Orissa Iron Ore Craton (SOIOC) contains a large number of iron ore deposits associated with the Iron Ore Group (IOG) (Figure 3). On the basis of tectonic analysis, the regional structure is a low NNE plunging synclinorium overturned towards SE. The iron ores found in these areas are a Banded Iron Formation (BIF; mainly present as BHJ, banded hematite jasper) hosted deposits. These ores are considered to be of secondary in nature resulting from the supergene enrichment of the host rocks and by gradual removal of silica from BIFs and locally from the ferruginous shales of the Iron ore group.

Mineralogically the iron ore deposits consist mainly of hematite together with variable amount of iron hydroxides (goethite, lepidocrocite, limonite). Magnetite occurs in small amount in some of the deposits, particularly in the deposits of the eastern basin; martite grains (pseudomorph of magnetite) are fairly common. Specularite is noted in some ores. The gangue minerals include quartz, chert, gibbsite and clay minerals (chiefly kaolinite).

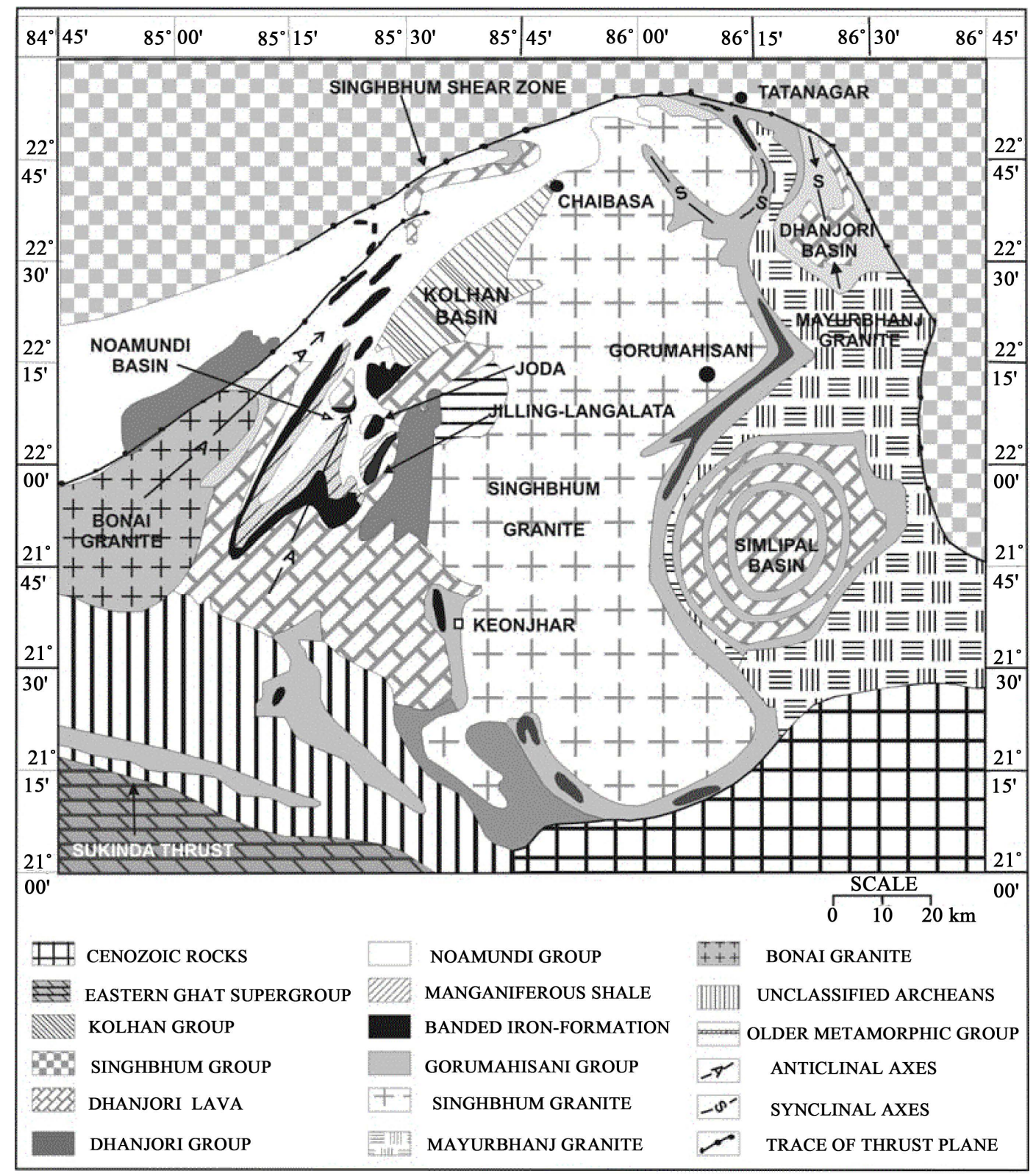

Figure 3. Generalised geological map of Singhbhum Orissa iron ore craton. 


\section{Methodology}

Characteristaion studies of three different types of iron ore from Joda mines were carried out. Each of the ores is classified as hard (HO), friable (FO) or soft ore (SO). The ores are further subdivided based on their alumina levels $(2 \%, 4 \%$, and $6 \%)$. The samples were crushed to get a size suitable for sintering (i.e., $-10 \mathrm{~mm}$ ). The crushed samples were characterised size wise for their chemical analysis. XRD, EPMA and Image analysis were done for characterisation of gangue and ore minerals. The aim of the mineralogical investigation is to describe the mineral associations and relationships to ascertain the character of the Al-bearing minerals present in the samples. The chemical analysis was done by ICP AES instrument.

The samples of all the three iron ores and their size fractions mentioned earlier, were pulverised and subjected to qualitative X-ray diffraction (XRD) analysis, using $\mathrm{Cu} \mathrm{K} \alpha$ radiation, a $2 \theta$ scan range of $10^{\circ}-90^{\circ}$, a step size of $0.02^{\circ} 2 \theta$, and a counting time of $1 \mathrm{~s}$ per step. Only crystalline phases in amounts sufficient to diffract (usually $\geq 3$ - 4 mass\%) under the conditions employed, were detected. The $-1 \mathrm{~mm}$ fraction was subjected to electron microprobe examination.

For EPMA and Image analysis same samples were used. EPMA was done by JEOL JXA-8230. For the optical microscopy each size fraction was crushed to $-3+1 \mathrm{~mm}$ and was mounted and polished. Carl Zeiss Axiovision 4 reflected light microscope integrated with an image analyser was used for the optical phase identification and quantification.

\section{Results and Discussion}

Characterisation studies of nine different types of iron ore from Joda mines were carried out. The size wise analysis of the ores (HO, FO, SO) are as presented in Table 1.

\subsection{Microscopic and EPMA Studies}

The mineral chemistry and association of different iron and gangue bearing phases was observed to be similar for different size fraction for individual type of ore. The amount of phases present and their elemental composition in different ore types are as given below in Table 2 and Table 3 respectively. It can be observed from Table 2 that as the alumina \% of ore types increases the amount of gangue minerals especially that of clay increases. The Hematite percentage decreases correspondingly.

The Table 3 gives a picture of the elemental composition of phases present in different types of ores. It is evident that the gangue content (Alumina and Silica) increases with increase in weathering intensity of ores (HO $\rightarrow \mathrm{FO} \rightarrow \mathrm{SO}$ ). Hematite is also present as re-precipitated hematite or secondary hematite and contains alumina as an impurity. This suggests that this type of hematite is re-precipitated from goethite. Goethite contains alumina and silica as a major impurity. Clay is ferruginous in nature.

A detailed description of individual types of ore texture is discussed below.

\subsubsection{Hard Ore}

Microscopic studies of hard ores indicate massive (Figure 4(a)) and banded structures of hematite (Figure 4(b)). Specularite and fine grained hematite grains are present as aggregates. Goethite exhibits a replacement texture with hematite (Figure 4(c)).

The EPMA studies show presence of alumina alongwith the iron minerals in voids (Figure 5, point 1 \& 3). The alumina is also present in goethite as layered texture (Figure 5, point 4). The hematite grains shows presence of insignificant amount of alumina may be present in adsorbed state (Figure 5, point 2 \& 5).

\subsubsection{Flaky Ores}

Ore microscopic studies of flaky-ores indicate that the clay minerals generally occur in the form of layering along with the hematite grains, as inter-granular cavity fillings and as veins (Figure 6(a)). Clay minerals are present as intercavity fillers (Figure 6(b)). Goethite is also found to be present in this ore type.

This type of ore shows an extensive amount of replacement as it has undergone higher degree of weathering. The goethite occurs as layered structure with alumina and clay minerals as alternate band (Figure 7). However, the hematite grains shows presence of insignificant amount of alumina in adsorbed state similar to the HO type ore as mentioned earlier. 


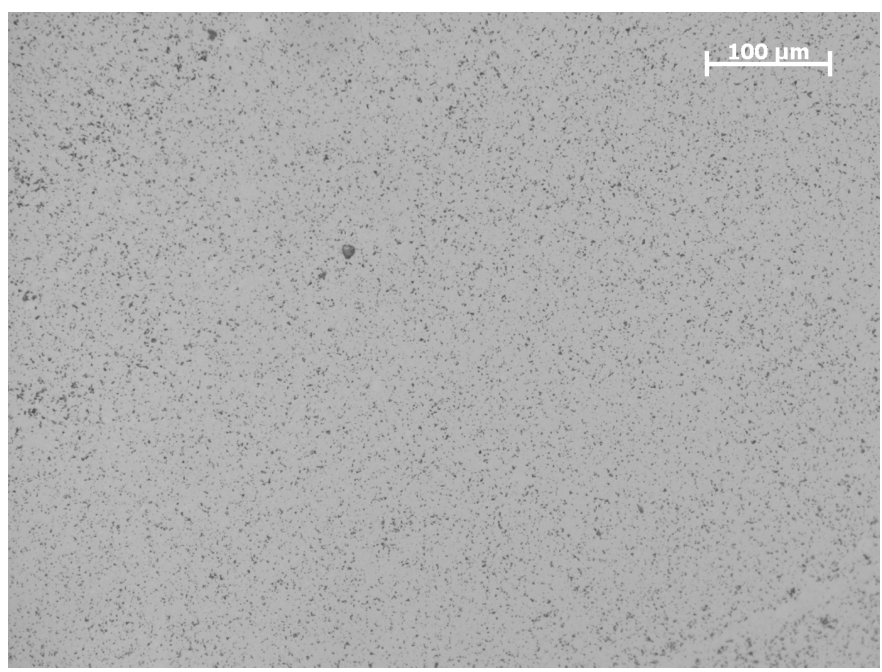

(a)

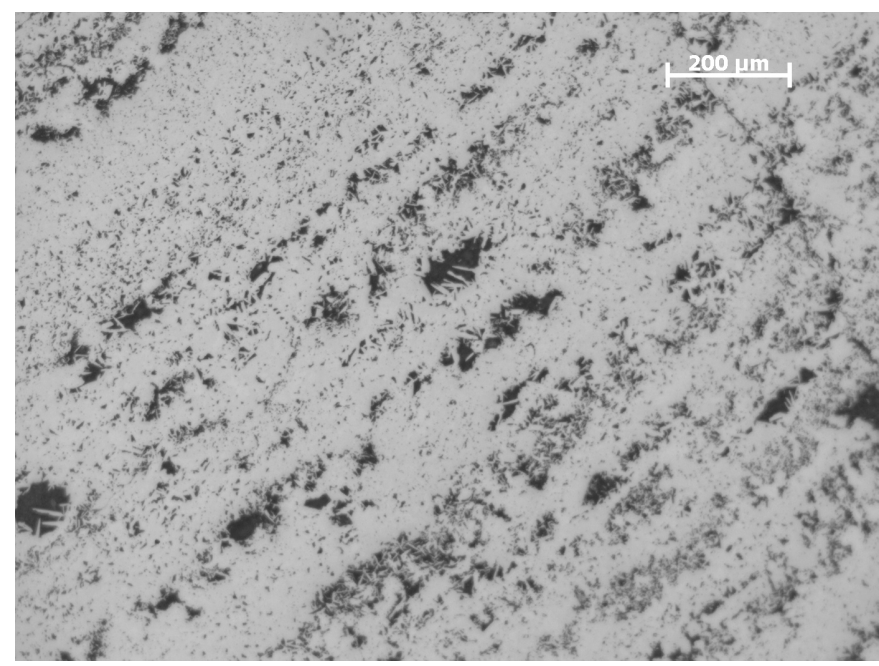

(b)

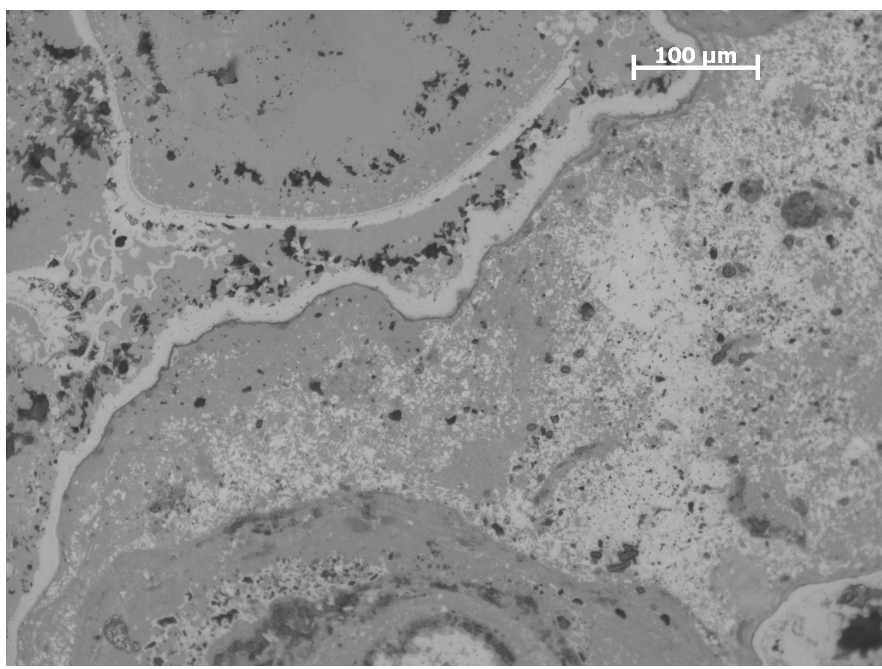

(c)

Figure 4. (a) Massive ore; (b) Banded structure; (c) Goethite. 


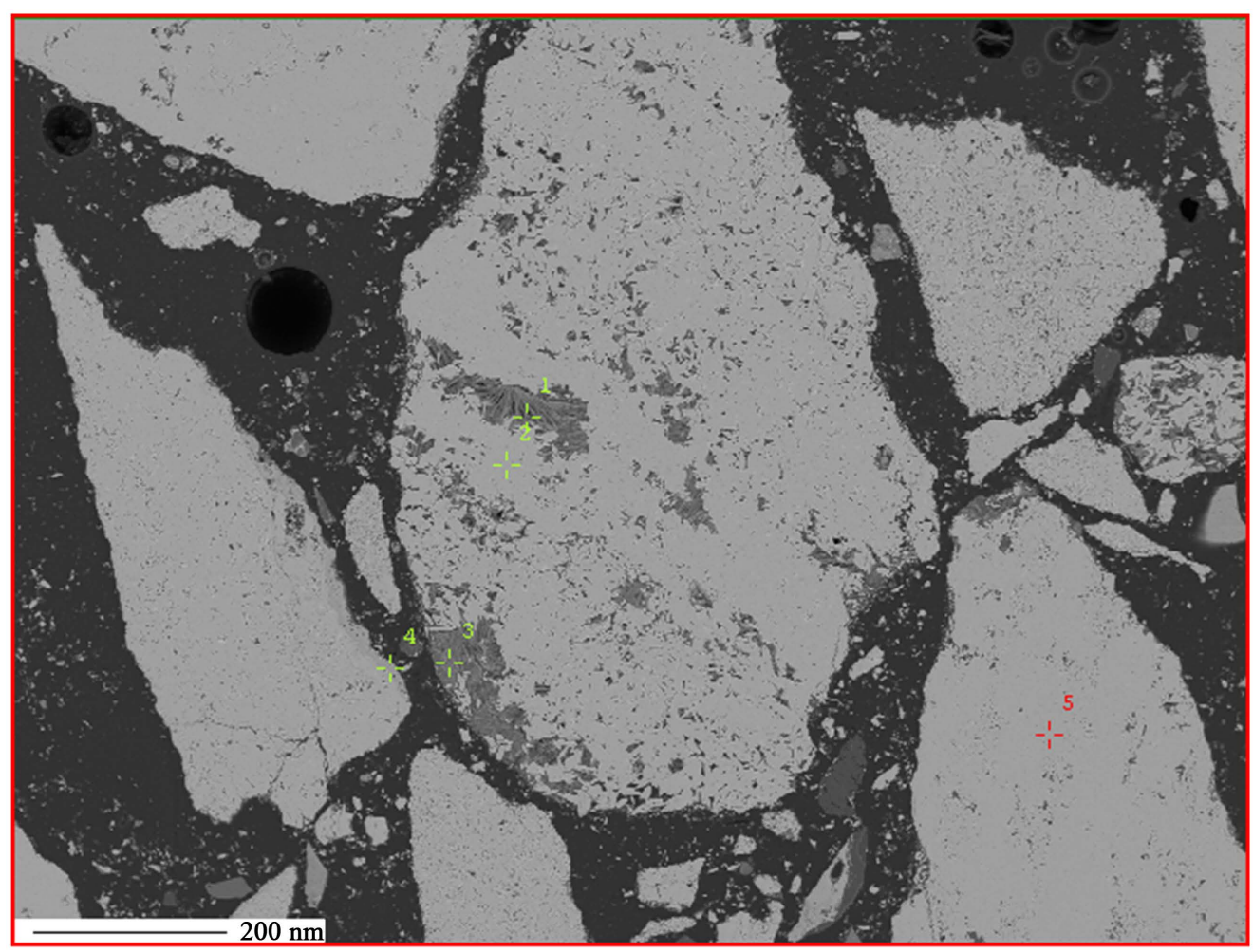

\begin{tabular}{|c|c|c|c|}
\hline Point & \multicolumn{3}{|c|}{ Element mass\% } \\
\hline $\mathbf{H O}$ & $\mathbf{A l}_{\mathbf{2}} \mathbf{O}_{\mathbf{3}}$ & $\mathbf{S i O}_{\mathbf{2}}$ & $\mathbf{F e O}$ \\
\hline 1 & 33.96 & 1.09 & 64.95 \\
\hline 2 & 0.01 & 0.58 & 99.41 \\
\hline 3 & 31.30 & 1.21 & 67.49 \\
\hline 4 & 7.28 & 0.85 & 91.87 \\
\hline 5 & 0.12 & 0.00 & 99.88 \\
\hline
\end{tabular}

Figure 5. EPMA analysis of HO type ore. Figure on top is a BSE image from EPMA.

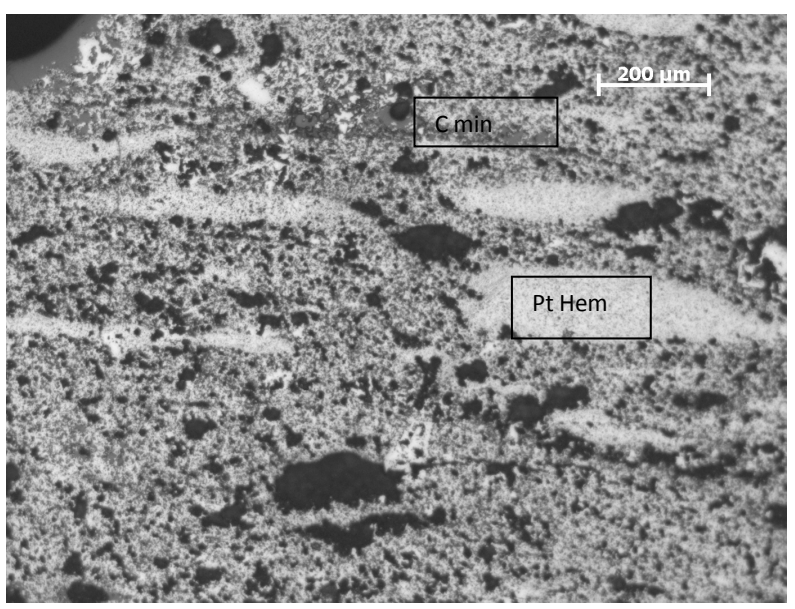

(a)

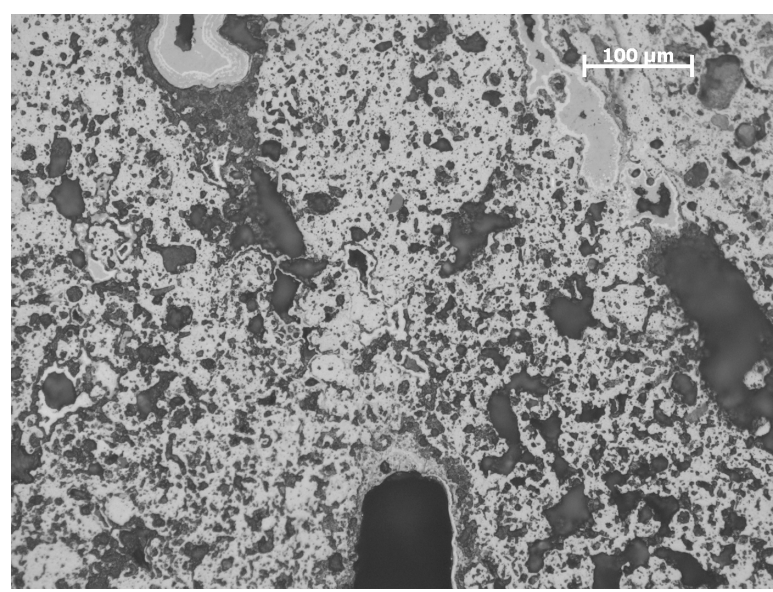

(b)

Figure 6. (a) Microplaty hematite (Pt hem) and Clay minerals (C min) in FO type ore; (b) Goethite with clay minerals as intercavity fillers. 
Table 1. Size wise chemical analysis of ores.

\begin{tabular}{|c|c|c|c|c|c|c|c|c|c|}
\hline Sample ID & $\mathbf{F e}(\mathrm{T})$ & $\mathrm{SiO}_{2}$ & $\mathrm{Al}_{2} \mathrm{O}_{3}$ & LOI & Sample ID & Fe (T) & $\mathrm{SiO}_{2}$ & $\mathrm{Al}_{2} \mathrm{O}_{3}$ & LOI \\
\hline HO $2 \%$ BULK & 66.92 & 0.32 & 1.16 & 1.89 & FO $2 \%$ BULK & 65.65 & 2.18 & 1.63 & 1.59 \\
\hline HO $2 \%(+8 \mathrm{~mm})$ & 67.59 & 0.59 & 0.56 & 2.00 & FO $2 \%(+8 \mathrm{~mm})$ & 67.4 & 0.24 & 0.9 & 1.68 \\
\hline HO $2 \%(+6 \mathrm{~mm})$ & 67.47 & 0.86 & 0.90 & 1.00 & FO $2 \%(+6 \mathrm{~mm})$ & 67.36 & 0.17 & 1.02 & 1.75 \\
\hline HO $2 \%(+3 \mathrm{~mm})$ & 67.30 & 0.76 & 1.15 & 1.09 & FO $2 \%(+3 \mathrm{~mm})$ & 67.58 & 0.28 & 0.84 & 1.50 \\
\hline HO $2 \%(+1 \mathrm{~mm})$ & 65.92 & 1.02 & 1.40 & 1.81 & FO $2 \%(+1 \mathrm{~mm})$ & 65.16 & 1.96 & 1.36 & 2.16 \\
\hline HO 2\% (-1 mm) & 64.28 & 1.50 & 2.28 & 2.50 & FO $2 \%(-1 \mathrm{~mm})$ & 63.08 & 3.69 & 2.1 & 2.51 \\
\hline HO 4\% BULK & 62.00 & 2.35 & 3.19 & 4.32 & FO 4\% BULK & 61.04 & 4.43 & 4 & 3.80 \\
\hline $\mathrm{HO} 4 \%(+8 \mathrm{~mm})$ & 61.86 & 2.13 & 3.43 & 5.06 & FO $4 \%(+8 \mathrm{~mm})$ & 64.85 & 2.27 & 2.03 & 2.68 \\
\hline HO 4\% (+6 mm) & 64.90 & 1.59 & 2.19 & 2.84 & FO 4\% (+6 mm) & 64.82 & 2.35 & 2.11 & 2.60 \\
\hline HO 4\% (+3 mm) & 63.28 & 1.99 & 2.92 & 3.92 & FO $4 \%(+3 \mathrm{~mm})$ & 64 & 2.9 & 2.44 & 2.92 \\
\hline $\mathrm{HO} 4 \%(+1 \mathrm{~mm})$ & 54.92 & 3.96 & 5.36 & 7.98 & FO $4 \%(+1 \mathrm{~mm})$ & 61.22 & 3.7 & 3.9 & 3.73 \\
\hline $\mathrm{HO} 4 \%(-1 \mathrm{~mm})$ & 65.6 & 1.39 & 2.04 & 2.30 & FO 4\% (-1 mm) & 56.2 & 7 & 6.42 & 5.42 \\
\hline HO 6\% BULK & 53.65 & 4.61 & 7.78 & 9.70 & FO 6\% BULK & 57.6 & 6.08 & 5.65 & 5.10 \\
\hline HO $6 \%(+8 \mathrm{~mm})$ & 60.58 & 2.68 & 3.98 & 5.96 & FO 6\% (+8 mm) & 60.04 & 4.86 & 4.6 & 4.10 \\
\hline HO 6\% (+6 mm) & 55.28 & 3.87 & 5.73 & 10.21 & FO $6 \%(+6 \mathrm{~mm})$ & 59.61 & 5.15 & 5.05 & 4.20 \\
\hline HO 6\% (+3 mm) & 58.64 & 3.08 & 4.72 & 7.66 & FO 6\% (+3 mm) & 59.45 & 4.79 & 4.86 & 4.77 \\
\hline HO 6\% (+1 mm) & 56.34 & 3.52 & 5.52 & 9.40 & FO 6\% (+1 mm) & 57.35 & 6.08 & 5.85 & 5.52 \\
\hline HO 6\% (-1 mm) & 55.41 & 3.76 & 5.68 & 10.22 & FO 6\% (-1 mm) & 51.2 & 10.18 & 8.88 & 7.05 \\
\hline Sample ID & Fe (T) & $\mathrm{SiO}_{2}$ & $\mathbf{A l}_{2} \mathbf{O}_{3}$ & LOI & & & & & \\
\hline SO 2\% BULK & 66.34 & 1.01 & 1.24 & 1.73 & & & & & \\
\hline SO $2 \%(+8 \mathrm{~mm})$ & 65.71 & 1.91 & 1.21 & 1.31 & & & & & \\
\hline SO $2 \%(+6 \mathrm{~mm})$ & 66.39 & 1.17 & 1.02 & 1.22 & & & & & \\
\hline SO $2 \%(+3 \mathrm{~mm})$ & 64.33 & 0.81 & 0.86 & 4.86 & & & & & \\
\hline SO $2 \%(+1 \mathrm{~mm})$ & 66.23 & 1.20 & 1.14 & 1.27 & & & & & \\
\hline SO $2 \%(-1 \mathrm{~mm})$ & 64.82 & 1.83 & 2.05 & 2.09 & & & & & \\
\hline SO 4\% BULK & 60.67 & 2.34 & 3.82 & 6.14 & & & & & \\
\hline $\mathrm{SO} 4 \%(+8 \mathrm{~mm})$ & 64.64 & 1.84 & 2.05 & 2.92 & & & & & \\
\hline $\mathrm{SO} 4 \%(+6 \mathrm{~mm})$ & 63.55 & 1.81 & 2.92 & 3.94 & & & & & \\
\hline $\mathrm{SO} 4 \%(+3 \mathrm{~mm})$ & 63.23 & 1.66 & 2.94 & 4.48 & & & & & \\
\hline $\mathrm{SO} 4 \%(+1 \mathrm{~mm})$ & 61.72 & 1.8 & 3.33 & 5.93 & & & & & \\
\hline SO $4 \%(-1 \mathrm{~mm})$ & 57.64 & 3.77 & 4.8 & 7.62 & & & & & \\
\hline SO 6\% BULK & 56.33 & 4.13 & 6.04 & 8.12 & & & & & \\
\hline SO $6 \%(+8 \mathrm{~mm})$ & 60.78 & 2.47 & 4.82 & 4.98 & & & & & \\
\hline SO $6 \%(+6 \mathrm{~mm})$ & 59.59 & 2.61 & 5.73 & 5.78 & & & & & \\
\hline SO $6 \%(+3 \mathrm{~mm})$ & 56.76 & 3.12 & 7.13 & 7.68 & & & & & \\
\hline SO $6 \%(+1 \mathrm{~mm})$ & 55.60 & 3.52 & 8.09 & 7.95 & & & & & \\
\hline SO 6\% (-1 mm) & 53.88 & 4.21 & 8.66 & 9.04 & & & & & \\
\hline
\end{tabular}




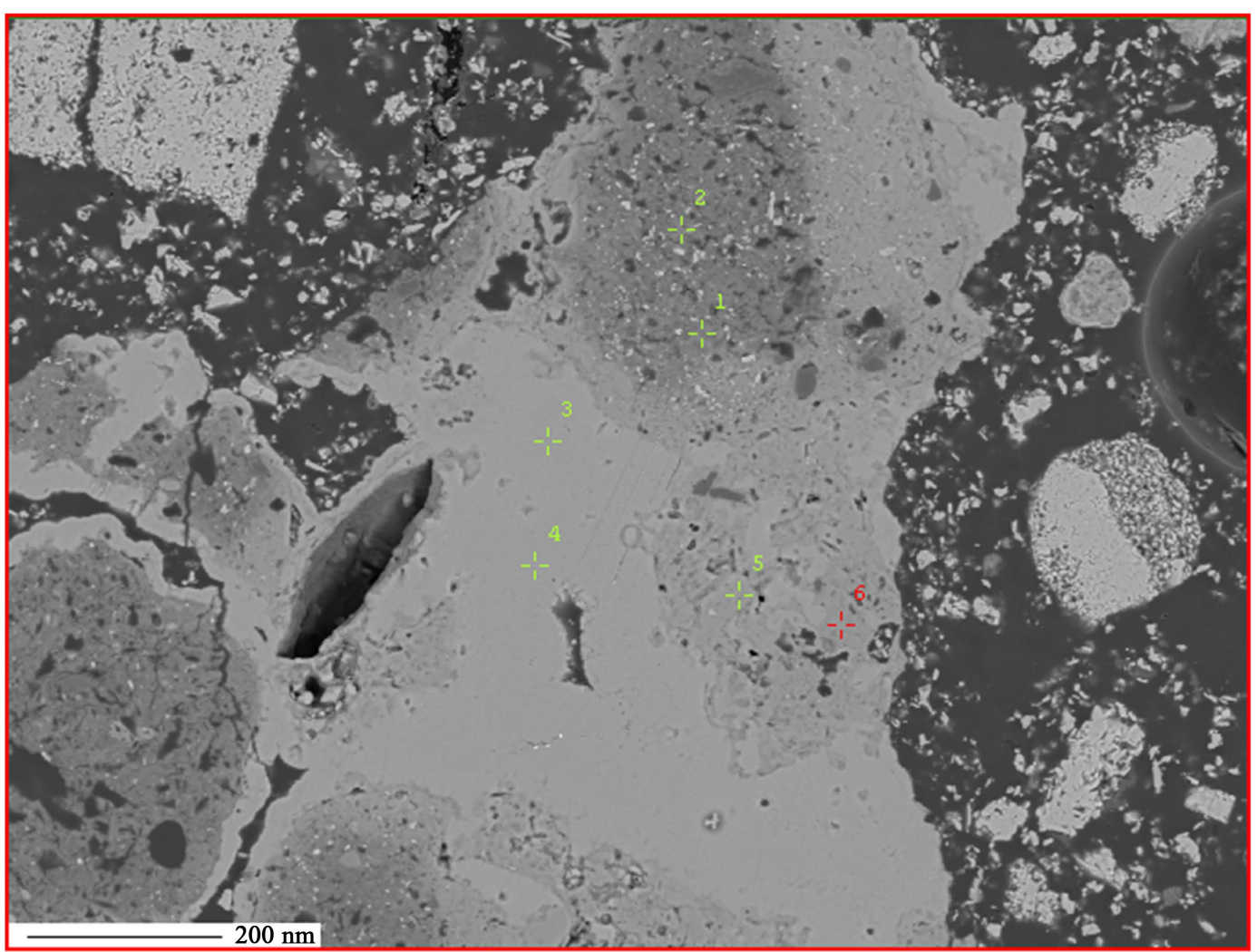

\begin{tabular}{|c|c|c|c|}
\hline Point & \multicolumn{3}{|c|}{ Element mass \% } \\
\hline $\mathrm{FO}$ & $\mathrm{Al}_{2} \mathrm{O}_{3}$ & $\mathrm{SiO}_{2}$ & $\mathrm{FeO}$ \\
\hline 1 & 16.36 & 0.41 & 83.23 \\
\hline 2 & 16.15 & 0.85 & 83.00 \\
\hline 3 & 0.00 & 0.68 & 99.32 \\
\hline 4 & 0.14 & 0.61 & 99.26 \\
\hline 5 & 9.48 & 0.59 & 89.93 \\
\hline 6 & 9.90 & 0.50 & 89.61 \\
\hline
\end{tabular}

Figure 7. EPMA analysis of FO type ore. Figure on top is a BSE image from EPMA.

Table 2. Phase \% in different ore types.

\begin{tabular}{ccccc}
\hline Sample ID & Hematite & Goethite & Gibbsite & Clay \\
\hline HO 2\% & 91.92 & 3.13 & 2.19 & 2.76 \\
HO 4\% & 84.37 & 3.19 & 4.01 & 8.43 \\
HO 6\% & 68.98 & 5.17 & 4.41 & 21.44 \\
FO 2\% & 89.10 & 3.17 & 3.08 & 4.66 \\
FO 4\% & 81.10 & 4.12 & 3.78 & 11.01 \\
FO 6\% & 74.06 & 5.55 & 3.20 & 17.19 \\
SO 2\% & 90.03 & 3.20 & 2.34 & 4.43 \\
SO 4\% & 80.60 & 4.10 & 3.61 & 11.69 \\
SO 6\% & 74.42 & 5.43 & 3.42 & 16.72 \\
\hline
\end{tabular}


Table 3. Elemental composition of different phases by EPMA.

\begin{tabular}{ccccc}
\hline Phases & Ore types & FeO & $\mathbf{A l}_{2} \mathbf{O}_{3}$ & $\mathbf{S i O}_{2}$ \\
\hline \multirow{2}{*}{ Hematite } & HO & 99.5 & 0.1 & 0.4 \\
& FO & 98.7 & 0.6 & 0.6 \\
SO & HO & 98.2 & 1.0 & 0.9 \\
H (Secondary) & FO & 91.9 & 7.1 & 1.0 \\
& SO & 92.2 & 6.9 & 1.2 \\
Goethite & HO & 94.6 & 4.2 & 2.8 \\
& FO & 89.1 & 8.1 & 4.3 \\
& SO & 84.6 & 11.1 & 1.8 \\
Clay (Ferruginous) & HO & 91.4 & 6.8 & 33.9 \\
& FO & 33.4 & 32.7 & 47.6 \\
& SO & 14.3 & 38.2 & 42.9 \\
\hline
\end{tabular}

\subsubsection{Soft Ore}

As the name suggests this ore is very soft in nature and has undergone cycles of weathering. This resembles the hard laminated ore in texture/appearance. This ore also seems to be hydrated and has undergone weathering, as a result goethiticminerals is in abundance. The replacement texture is visible. The ore mineral has been leached out, and the voids thus created is filled in by the clay and goethitic minerals (Figure 8(a) and Figure 8(b)).

Apart from hematite, goethite dominates the soft ore mineralogy. It is mainly present as replacement texture and occurs in bands like previous ores (Figure 9). The alumina content in goethite and other gangue minerals are significantly higher than the other ore types.

\subsection{XRD Analysis}

The XRD pattern of the iron ores indicates presence of hematite and goethite, while clay minerals and gibbsite are not traceable. It can be observed clearly from the pattern that as the alumina level as well as weathering intensity increases $(\mathrm{HO} \rightarrow \mathrm{FO} \rightarrow \mathrm{SO}$ ), the goethite peak intensity is higher (Figure 10). The peak shape however indicates a poorly crystalline goethite. This indicates the presence of alumina in goethite. This is confirmed by the EPMA studies of the iron ores (Figure 5, Figure 7 and Figure 9).

\section{Summary}

1) In general, hematite and goethite are major iron bearing minerals. The Al-bearing minerals in the assemblage are gibbsite, clay and goethite. Silica is mainly in the form of quartz and occur in all the iron ore samples. Occasionally accessory rutile and/or zircon were also observed.

2) Hematite is present as microplaty, specular or banded texture. EPMA studies show presence of alumina adsorbed on the surface of the hematite grains. The concentration is very low ( 0.14 - 0.3) as detected by EPMA. The above is true for all the ore types.

3) Hematite is also present as re-precipitated hematite or secondary hematite and contains alumina as an impurity. This suggests that this type of hematite is re-precipitated from goethite.

4) As the alumina \% of ore types increases the amount of gangue minerals especially that of clay increases. The Hematite percentage decreases correspondingly. 


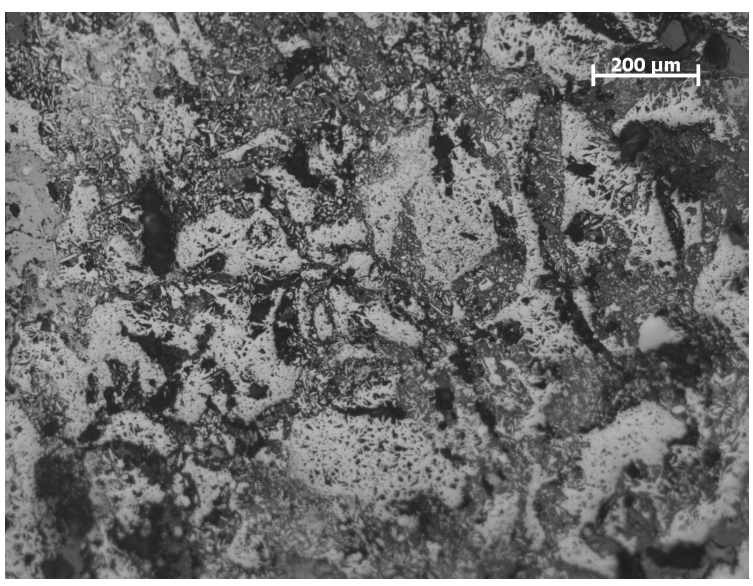

(a)

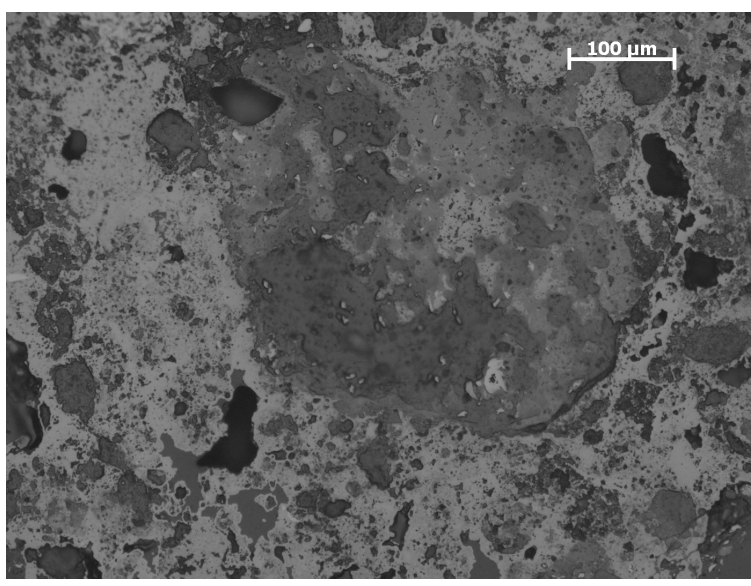

(b)

Figure 8. (a) Replacement texture; (b) Goethite.

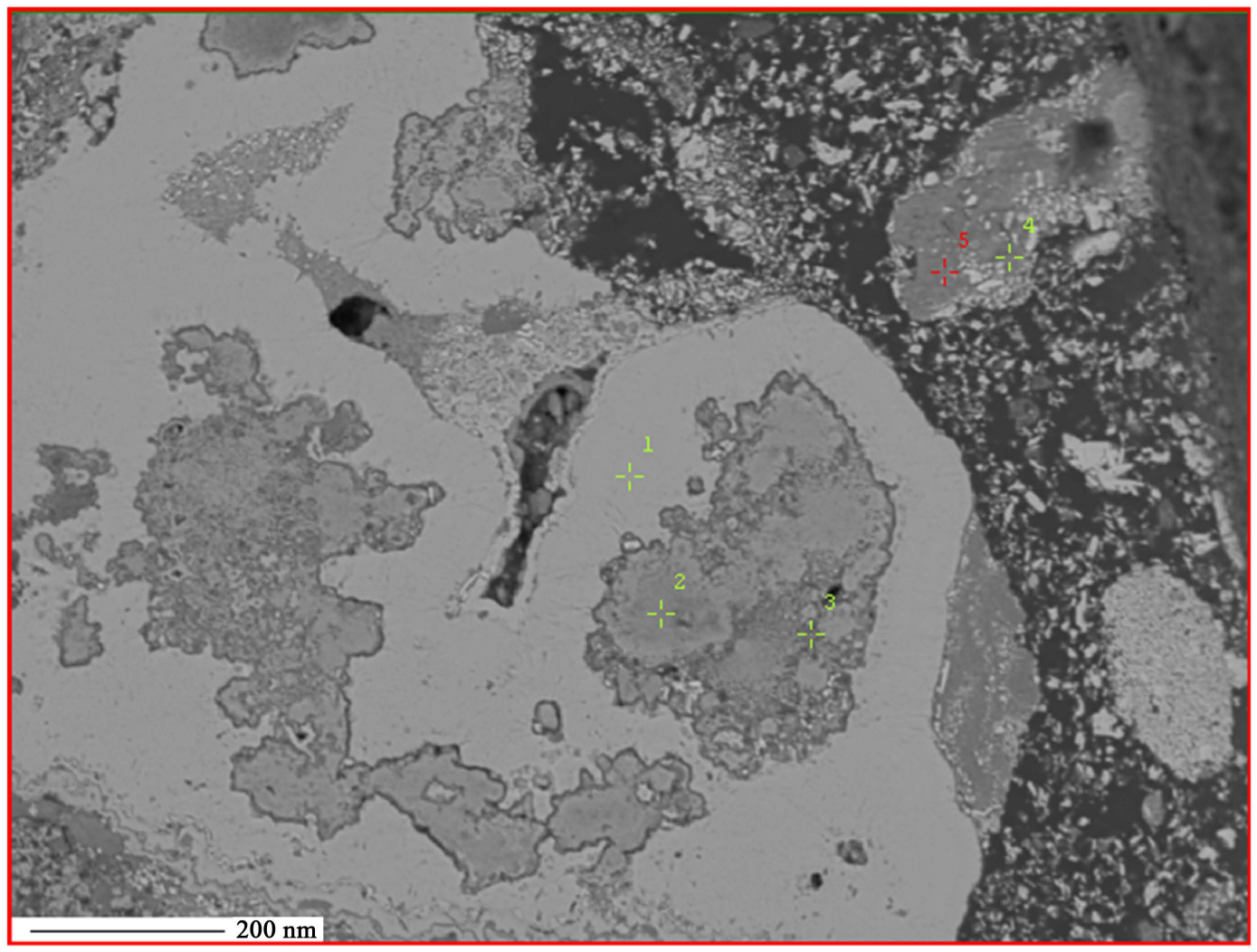

\begin{tabular}{|c|c|c|c|}
\hline Point & \multicolumn{3}{|c|}{ Element mass \% } \\
\hline SO & $\mathrm{Al}_{2} \mathrm{O}_{3}$ & $\mathrm{SiO}_{2}$ & $\mathrm{FeO}$ \\
\hline 1 & 0.49 & 0.77 & 98.75 \\
\hline 2 & 13.82 & 0.53 & 85.65 \\
\hline 3 & 9.82 & 2.00 & 88.17 \\
\hline 4 & 19.04 & 12.27 & 68.68 \\
\hline 5 & 13.95 & 5.52 & 80.53 \\
\hline
\end{tabular}

Figure 9. EPMA analysis of SO type ore. Figure on top is a BSE image from EPMA. 


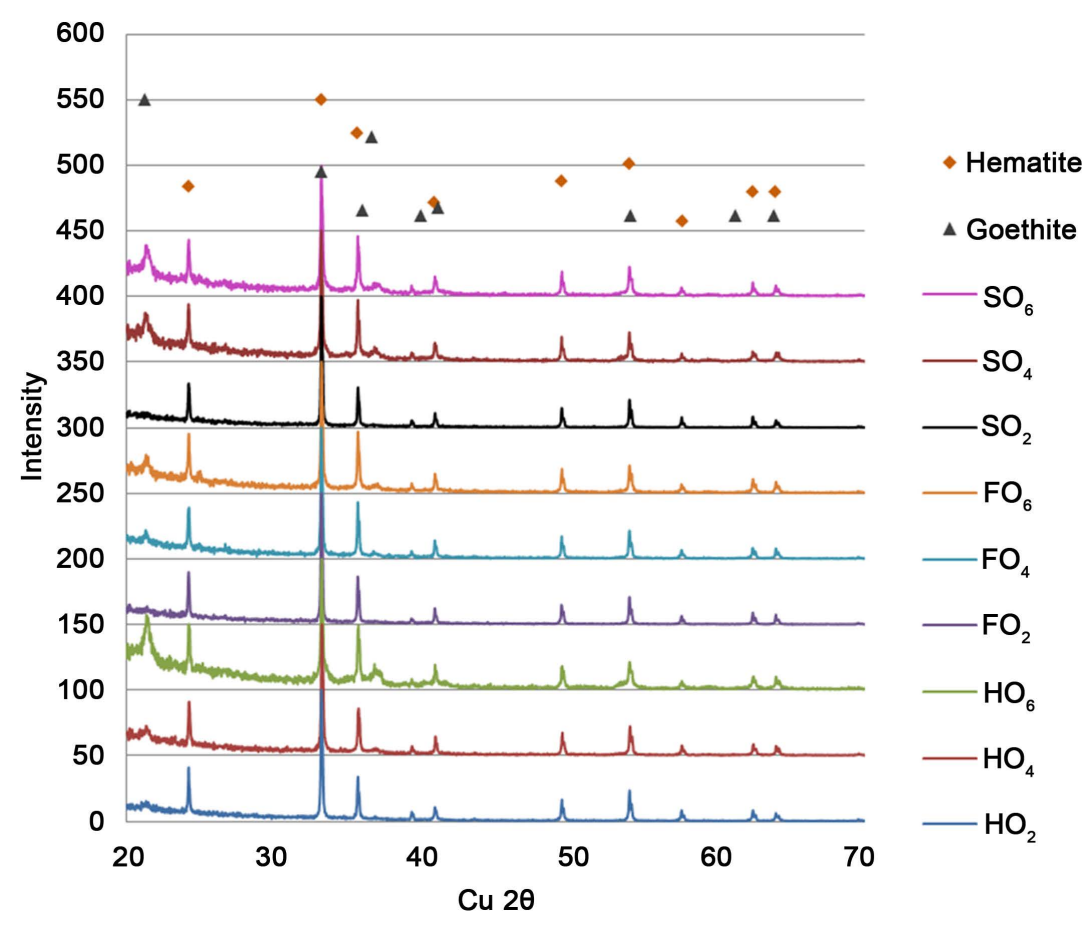

Figure 10. XRD pattern of bulk ore.

5) It is evident that the gangue content (Alumina and Silica) increases with increase in weathering intensity of ores $(\mathrm{HO} \rightarrow \mathrm{FO} \rightarrow \mathrm{SO})$.

6) The ores also contains significant amount of secondary iron minerals (goethite) and clay. The goethite commonly found in this iron ores is colloform banded goethite and massive goethite. Goethite exhibits replacement relationship with hematite.

7) Hematite dominates the bulk samples, whereas clay is a significant component of the $-1 \mathrm{~mm}$ size fraction.

8) The associated gangue minerals esp. clay is ferruginous in nature. The ultrafine coating particles consist of hematite, poorly crystalline goethite and clay minerals.

9) Alumina and clay minerals tend to get deposited in the cavities and thus are present as fillers in the cavity, cracks and pores of the mineral grains.

10) As expected, the higher the alumina percentage, higher the weight loss was observed in the mentioned ore types.

\section{Conclusions}

XRD studies revealed hematite as the major minerals with subordinate amounts of goethite, confirming the microscopic findings. Qualitative mapping and quantitative EPMA studies on these ores indicated the presence of gibbsite as the only alumina bearing phase. Clay is one of the major sources of alumina. Traces of alumina, present as solid solution in the hematite phase, have also contributed to the ores. Electron microscopic studies revealed that gibbsite grains are in the size range of 10 - 50 microns and are intimately and intricately present along with the iron oxide phases.

The studied ore types have a significant amount of goethite, and especially the $4 \%$ and $6 \%$ alumina level ores are very high in goethite and clay minerals, and thus the solid fuel rate requirement is expected to be higher than the other hematite ores. However the reducibility is expected to improve. Due to high gangue content, the amount of amorphous phases, as well, in sinter can be high.

The sinter feed is a blend of different types of iron ores. Thus, the information about the ratio of mixing of different ores can give an insight about the quality expected. Also, mineralogy of a given iron ore is one of the most relevant aspects and should be considered in preparation of sinter blends. By increasing the knowledge on the characteristics of different ore types, its influence on sinter properties will help define measures which can neutralize, dilute/localize the effects of alumina on the sinter quality. 


\section{References}

[1] Loo, C.E. (2005) A Perspective of Geothitic Ore Sintering Fundamentals. ISIJ, 45, 436-448. http://dx.doi.org/10.2355/isijinternational.45.436

[2] Lu, L., Holmes, R.J. and Manuel, J.R. (2007) Effects of Alumina on Sintering Performance of Hematite Iron Ores. ISIJ, 47, 349-358. http://dx.doi.org/10.2355/isijinternational.47.349

[3] Pecchio, et al., Eds. (2004) Applied Mineralogy. ICAM-BR, São Paulo.

[4] Yang., L.X. (2005) Sintering Fundamentals of Magnetite Alone and Blended with Hematite and Hematite/Goethite Ores. ISIJ International, 45, 469.

[5] Panigrahy, S.C., Rigaud, M.A.J. and Dilewijns, J. (1985) Effect of Dolomite Addition on the Properties of Sintered Ore Produced from the High Iron Ore of Alumina. Steel Research, 56, 35.

[6] Pimenta, H.P. and Seshadri, V. (2002) Influence of $\mathrm{Al}_{2} \mathrm{O}_{3}$ and $\mathrm{TiO}_{2}$ Degradation Behaviour of Sinter and Hematite at Low Temperatures on Reduction. Ironmaking Steelmaking, 29, 175-179. http://dx.doi.org/10.1179/030192302225001992

[7] Caparoli, L. (1998) ICSTI, Iron Ore Micro Structure Properties-Performance Relation in Sintering Process. Ironmaking Steelmaking Conference Proceedings (B), 3, 123-135.

[8] Okazaki, et al. (2001) Advanced Approach to Intelligent Iron Making Processes. Effect of Mineralogical Properties of Iron Ore on Pore Formation of Sinter. Tetsu-to-Hagané, 87, 298-304.

[9] Goldring, D.C. (2003) Iron Ore Categorisation for the Iron and Steel Industry. Applied Earth Science, 112, 5-17. http://dx.doi.org/10.1179/0371745032501162 